\title{
Prospek Negara Hukum Indonesia: Gagasan dan Realita
}

\author{
Prospects of the Constitutional State of Indonesia: Ideas and Reality
}

\author{
Hamdan Zoelva \\ Fakultas Hukum, Universitas Islam As-Syafi'iyah \\ Jln. Raya Jatiwaringin, Pondok Gede, 17411, Jakarta, Indonesia. \\ Tel./Fax:+62-218484719 E-mail: hamdanzoelva@yahoo.com \\ Submitted: Jul 12, 2015; Reviewed: Jul 27, 2015; Accepted: Aug 4, 2015
}

\begin{abstract}
Indonesia since its inception has asserted itself as a constitutional state. It may be inferred through the clear regulation related to powers and functions of each state institution in the form of checks and balances system, the protection of human rights, the clarity of the principles of democratic mechanism, as well as the guarantee of an independent judiciary. Although the constitution has been set in such a way, efforts to achieve a constitutional state is not an easy road. Nowadays, it seems that the trip of the Indonesian as a constitutional state was still hobbled. A variety of legal issues that disturb the sense of justice continues to emerge one after another. The outcomes of the research indicate that over the last decade, Indonesia has made many changes to realize the ideal of a constitutional state. As it turns out in practice, however, legal development was still far short from the expectations. The success of building a constitutional state can not be measured by the ability to produce legislation and to create or revitalize legal institutions. Moreover, the success of a constitutional state must also be measured by the implementation and law enforcement which able to create justice for all people. Therefore, the main focus of various studies of law and legal policy, must be oriented in the judicial institutions and law enforcement.
\end{abstract}

Keywords: Constitution; Constitutional State; Rechtsstaat; Rule of Law

Abstrak: Indonesia sejak awal telah menegaskan dirinya sebagai sebuah negara hukum. Hal itu tampak pada adanya pengaturan yang jelas terkait kekuasaan dan fungsi masingmasing lembaga negara dalam bentuk sistem checks and balances antar cabang kekuasaan, jaminan perlindungan HAM yang cukup lengkap, kejelasan prinsip-prinsip mekanisme demokrasi, serta jaminan peradilan yang independen. Meskipun konstitusi telah mengatur sedemikian rupa, upaya mewujudkan negara hukum bukanlah hal yang mudah. Sekarang ini nampak perjalanan negara hukum Indonesia terasa masih tertatih-tatih. Berbagai persoalan hukum yang mengusik rasa keadilan terus muncul silih berganti. Hasil penelitian menunjukkan bahwa lebih dari dasawarsa terakhir, Indonesia telah banyak melakukan perubahan untuk mewujudkan cita negara hukum. Namun pada praktiknya, pembangunan hukum terasa masih tetap jauh dari harapan. Keberhasilan membangun negara hukum tidak dapat diukur dari kemampuan memproduksi legislasi dan menciptakan atau merevitalisasi institusi hukum. Lebih dari itu, keberhasilan bernegara hukum harus pula diukur dari implementasi dan penegakan hukum yang mampu menciptakan keadilan bagi seluruh rakyat. Oleh karena itu, fokus utama berbagai kajian hukum dan kebijakan hukum, harus diorientasikan pada institusi peradilan dan penegakkan hukum.

Keywords: Konstitusi; Negara Hukum; Rechtsstaat; Rule of Law 


\section{PENDAHULUAN}

Kata negara hukum merupakan pengertian dari suatu kata majemuk, yaitu negara dan hukum. Dalam memberikan pengertiannya, setiap orang dapat memberikan bobot penilaian, baik terhadap kata hukum maupun terhadap kata negara. Demikian juga halnya dengan bobot nilai dari masing-masing negara hukum. ${ }^{1}$ Selama ini dipahami bahwa negara hukum itu memiliki unsur kategorikal seperti supermasi hukum, persamaan dalam hukum, proses hukum yang adil, penghormatan atas hak-hak asasi manusia, adanya badan-badan peradilan independen, dan lain sebagainya.

Jika suatu negara telah mengadopsi berbagai syarat normatif tersebut, secara otomatis negara itu akan dapat dikatakan sebagai negara hukum. Padahal, konsep negara hukum tidak hanya terbatas pada bagaimana suatu negara mengakui bahkan telah mengklaim berbagai syarat normatif tersebut. Jika yang terjadi seperti ini, maka secara tidak sadar kita telah terjebak pada konsep pemahaman yang serba normatif-positivistik. ${ }^{2}$ Konsep negara hukum, haruslah benar-benar terbukti dalam praktik apakah unsur-unsur kategorikal tersebut ditegakkan dalam kehidupan suatu negara.

Indonesia sejak awal telah menegaskan dirinya sebagai negara hukum, walaupun UUD 1945 (sebelum perubahan) tidak memuat pengaturan substansi yang memadai sehingga memenuhi ciri-ciri negara hukum. Perubahan UUD 1945, memberi makna yang

Baca Sunaryati Hartono. (1969). Apakah the Rule of Law. Bandung: Alumni, hal. 12.

2 Lihat pendapat tentang ini dalam Satjipto Rahardjo. (2009). Negara Hukum yang Membahagiakan Rakyatnya, Cetakan kedua. Yogyakarta: Genta Publshing. jelas mengenai negara hukum Indonesia. Hal itu tampak pada adanya pengaturan yang jelas kekuasaan dan fungsi masing-masing lembaga negara dalam bentuk sistem checks and balances antar cabang kekuasaan, jaminan perlindungan HAM yang cukup lengkap, kejelasan prinsip-prinsip mekanisme demokrasi, serta jaminan peradilan yang independen.

Meskipun konstitusi telah mengatur sedemikian rupa, upaya mewujudkan negara hukum bukanlah hal yang mudah. Sekarang ini nampak perjalanan negara hukum Indonesia terasa masih tertatih-tatih. Berbagai persoalan hukum yang mengusik rasa keadilan terus muncul silih berganti. Setelah lebih satu dasawarsa reformasi berlangsung (1998-2015) termasuk semangat melakukan reformasi hukum, belum memenuhi tuntutan keadilan yang terus berkembang. Seluruh aspek sistem hukum, baik aspek materi dan substansi hukum, misalnya sinkronisasi dan konsistensi norma hukum baik sinkronisasi vertikal maupun horizontal, integritas dan profesionalisme penegak hukum serta budaya hukum masyarakat, masih jauh dari harapan. Hal ini menunjukkan pembangunan hukum di Indonesia untuk mewujudkan negara hukum yang adil dan demokrastis yang mengabdi pada kepentingan rakyat dan bangsa belum sepenuhnya berjalan.

Lantas, bagaimana agar konsep negara hukum dapat berjalan dengan baik? Dalam hal ini yang ingin ditelusuri adalah mengapa realitas negara hukum Indonesia setelah masa reformasi belum juga mengantarkan pada perbaikan yang memuaskan? Disinilah analisis komprehensif dari sistem hukum menjadi penting untuk dikaji dan diperbin- 
cangkan. Tulisan ini tidak dimaksudkan untuk mengkaji secara menyeluruh dan mendalam semua aspek sistem hukum Indonesia dan mengagas suatu solusi, namun bertujuan mengangkat sejumlah persoalan penting yang relevan untuk menjadi bahan evaluasi guna mewujudkan Indonesia sebagai negara hukum yang dicita-citakan. Paling tidak mengungkap hal positif yang telah dicapai dan tantangan yang harus diselesaikan.

\section{ANALISIS DAN PEMBAHASAN}

\section{Gagasan dan Konsep Negara Hukum Indonesia}

\section{Konsepsi negara hukum Pancasila}

Tatkala disimpulkan Indonesia adalah negara hukum, pertama-tama hendaknya dirumuskan terlebih dahulu apakah konsep negara hukum Indonesia itu. Tahir Azhary, mengemukakan bahwa konsep negara hukum adalah genus yang terdiri dari paling tidak lima spesis, yaitu rechtstaats, rule of law, socialist legality, nomo krasi Islam serta negara hukum Pancasila atau negara hukum Indonesia. ${ }^{3}$ Konsep negara hukum, tidak lahir dari ruang hampa, tetapi dipengaruhi oleh situasi yang melingkupinya. Memahami konsep negara hukum Indonesia, haruslah ditelusuri dengan memahami latar belakang dan semangat yang melahirkan Indonesia merdeka, serta kenyatan sosial budaya yang melingkupi kehidupan kenegaraan dan kebangsaan Indonesia.

Cara demikian adalah bijaksana, seperti halnya, dalam memahami lahirnya kon-

Lihat Tahir Azhary. (2003). Negara Hukum, Suatu Study tentang Prinsip-prinsipnya Dilihat dari Segi Hukum Islam, Implementasinya pada Periode Negara Madinah dan Masa Kini, Edisi Kedua, Jakarta: Kencana, hlm. 83. sep rechtstaats di Eropa Kontinental yang dilatarbelakangi oleh kenyataan adanya despotisme raja-raja di Eropa yang menumpuk kekuasaan di pundaknya sehingga menjadi absolut. Oleh karena itu, konsep negara hukum menawarkan pembatasan kekuasaan melalui pemisahan kekuasaan, peradilan yng independen, penghormatan atas HAM, serta peradilan administrasi negara.

Demikian juga konsep rule of law yang menoropong perkembangan dan kenyataan praktik hukum di Inggris yang berbeda dengan negara-negara Eropa umumnya pada saat itu (awal abad 19), ada penghormatan atas hukum (supremacy of law), persamaan di depan hukum -tidak ada seorang pun yang berada di atas hukum, serta praktik pengadilan-pengadilan di Inggris yang mengakui dan menjamin perlindungan hak-hak dan kebebasan individu. ${ }^{4}$ Hal yang sama, ketika kita memahami konsep socialist legality yang lahir dari filsafat sosialisme komunis yang dianut oleh negara negara-negara komunis. Dengan bubarnya negara-negara komunis, konsep ini menjadi turut memudar. ${ }^{5}$

Konsep negara hukum Indonesia dapat digali dari rumusan dalam Pembukaan UUD

Lihat A.V. Dicey, Introduction to the study of the Law and the Constitution, Ninth Edition, London: MacMilland and Co, 1952, (Terjemahan Bahasa Indonesia, Pengantar Studi Hukum Konstitusi, Oleh Nurhadi, MA. Bandung: Nusa Media, 2008, hlm. 2002-2003. Dalam hal ini Tamanaha, mengemukan tiga elemen rule of law, yaitu government limited by law, formal legality dan rule of law not man. Lihat Brian $\mathrm{Z}$ Tamanaha, On The Rule of Law, Cambridge: Cambridge University Press, UK, 2004, hlm. 114 -126.

Walaupun konsep socialist legality telah memudar tetapi falsafah sosialisme tetap saja memengaruhi gerakan buruh dan sosialisme di berbagai belahan dunia yang sangat mempengaruhi sistem hukum di berbagai negara. Pernah sangat berpengaruh di Indonesia pada taahun 1960, ketika Indonesia menerapkan konsep "Demokrasi Terpimpin”. 
1945 yang memuat pernyataan kehendak dan cita lahirnya Indonesia merdeka, bersatu, adil dan berdaulat, serta rumusan falsafah negara yang terkandung dalam Pembukaan itu. Indonesia merdeka adalah Indonesia yang lahir dari perjuangan panjang melawan kekuasaan penjajahan Belanda oleh seluruh komponen bangsa yang beragam suku, etnis, bahasa, agama serta kerajaan-kerajaan dan kesulatanan kecil yang tersebar di seluruh wilayah nusantara yang menghendaki Indonesia merdeka, berastu, adil dan berdaulat. Ketika Indonesia merdeka, institusi-institusi peradilan untuk orang Indonesia belumlah mapan, kecuali pengadilan-pengadilan untuk golongan Eropa.

Dari kenyataan ini dapatlah digambarkan beberapa ciri negara hukum Indonesia antara lain, negara hukum yang harus mememperhatikan pluralisme dan kemajemukan bangsa Indonesia. Negara hukum yang menyadari adanya cita dan semangat lahirnya kesatuan hukum nasional yang berdaulat dan melepaskan diri dari pengaruh penjajah Belanda. Cita-cita dan semangat itu menggelora sejak masa awal kemerdekaan, sampai pada masa pemerintahan Orde Baru, tetapi kenyataan menunjukkan proses pematangan yang harus dilalui masih panjang.

Percobaan dan transplantasi berbagai sistem hukum, baik yang bersumber dari hukum Belanda, hukum adat, hukum Islam dan lain-lain masih belum mencapai format yang ideal. Misalnya, masih banyak akademisi dan para pegiat hukum masih menawarkan model atau sistem peradilan yang dianut oleh sistem hukum anglo-Amerika dalam lembaga peradilan. Kondisi demikian harus dipahami secara bijaksana, untuk menghar- gai semangat perbaikan dan penyempurnaan, walaupun secara konseptual mengganti sistem bukanlah hal mudah untuk dilakukan karena berkaitan dengan seluruh aspek sistem hukum.

Di samping itu, dalam konsep negara hukum Indonesia terdapat pula pengakuan eksplisit perihal adanya intervensi Tuhan dalam pencapaian kemerdekaan Indonesia yang dituangkan dalam pernyataan kemerdekaan itu, dengan kalimat "Dengan rahmat Allah yang maha kuasa...”. Oleh karena kepercayaan atas adanya kekuasaan Tuhan, para founding parents menjadikan pinsip Ketuhanan Yang Maha Esa, sebagai prinsip pertama dan utama dalam falsafah negara Indonesia, kata Oemar Seno Aji, sebagai causa prima. ${ }^{6}$

Dengan pengakuan dan dasar yang demikian, bangsa Indonesia adalah bangsa yang ber-Tuhan, beragama dan tidak dimungkinkan untuk melakukan kampanye anti Tuhan atau pun anti agama. Jadi keragaman, kesatuan hukum nasional serta Ketuhanan menjadi ciri yang tidak bisa diabaikan dalam memahami konsep negara hukum Indonesia. Hal itu tentu menjadi sangat berbeda dengan berbagai konsep negara hukum yang ada di belahan dunia yang lain, yang tidak menjadikan unsur Ketuhanan sebagai unsur yang penting. Demikian juga dengan ciri keragaman dan semangat kesatuan hukum yang mengakibatkan tantangan pembangunan dan pematangan negara hukum Indonesia menjadi lebih rumit, karena tidak mudah membuat kesatuan hukum nasional dalam kondisi bangsa yang sangat maje-

Lihat Oemar Seno Aji. (1980). Peradilan Bebas Negara Hukum, Jakarta: Erlangga, hlm. 25. 
muk. Itulah sebabnya, penafsiran hukum dan pemahaman atas suatu ketentuan hukum yang berlaku di Indonesia sangat mungkin berbeda karena perbedaan latar belakang sosial dan budaya masyarakat.

Di samping ketiga prinsip di atas, dalam Pancasila terkandung pula prinsip kerakyatan dan musyawarah yang sangat memengaruhi hukum tata negara dan demokrasi di Indonesia serta sangat menekankan pentingnya prinsip keadilan sosial dalam pembangunan hukum dan ekonomi Indonesia. Prinsip persatuan Indonesia, kerakyatan dan musyawarah serta keadilan sosial inilah yang menurut Soekarno merupakan cerminan sifat asli bangsa Indonesia, yang menurutnya pula apabila Pancasila itu diperas menjadi satu, maka ada prinsip gotong royong, itulah dasar dan jiwa bangsa Indonesia. Ciri-ciri inilah, antara lain yang memberikan nuansa berbeda antara negara hukum Indonesia atau negara hukum Pancasila dengan negara hukum yang dianut di belahan dunia yang lain yang menonjolkan liberalisme, kebebasan individu dan dignity of man. ${ }^{7}$

Dalam menggambarkan negara hukum Barat adalah sangat tepat apa yang ditulis oleh Tamanaha bahwa karakteristik tradisi politik Barat sangat menekankan pada idiom "freedom under the rule of law". Hal itu tergambar, misalnya dalam pernyataan Presiden Amerika Serikat, George W. Bush, sebagaimana dikutip Tamanaha, "Amerika will always stand firm for the non-negotiable

Lihat Hamdan Zoelva, "Negara Hukum dalam Perspektif Pancasila” dalam Kongres Pancasila: Pancasila dalam Berbagai Perspektif, Jakarta: Sekretariat Jenderal dan Kepaniteraan Mahkamah Konstitusi, 2009, hlm. 222. demands of human dignity". 8

Dalam perjalanan sejarah hukum bangsa Indonesia, sistem hukum sangat dipengaruhi oleh situasi dan perkembangan politik yang terjadi pada suatu masa. Pada masa pemerintahan Presiden Soekarno, begitu sangat kuat menghendaki hukum dipengaruhi oleh ajaran sosialisme sehingga pernah beberapa akademisi menawarkan bahwa negara hukum Pancasila itu adalah negara hukum yang sama dengan konsep socialist legality. Pada masa pemerintahan Soeharto sangat dipengaruhi oleh prinsip bahwa hukum harus berperan dalam akselerasi pembangunan, sehingga seringkali aspek penghormatan atas hak asasi manusia diabaikan untuk menjamin kelanjutan dan percepatan pembangunan ekonomi. Hukum sering terkooptasi oleh kekuasaan dengan alasan pembangunan ekonomi. Hukum adalah alat bagi pembangunan, hal yang sangat dikhawatirkan oleh Tamanaha dalam bukunya Law as a means to an end (Law in context), yaitu bila hukum menjadi alat, di situlah ancaman terhadap terhadap negara hukum. ${ }^{9}$

\section{Negara hukum dalam perubahan UUD NRI 1945}

Hal lain yang perlu dikemukakan dalam tulisan ini adalah gambaran selintas mengenai konsep negara hukum pada Perubahan UUD NRI 1945. Sebagaimana disebutkan di atas, sebelum perubahan UUD NRI 1945, istilah negara hukum terdapat dalam Penjelasan

Brian Z. Tamanaha, On The Rule Of Law...op.cit., hlm. 2 .

9 Lihat selengkapnya Brian Z. Tamanaha, (2006). Law as a means to an end (Law in context), Cambridge: Cambridge University Press, hlm. 16. 
UUD NRI 1945. Menurut Bagir Manan, penjelasan dengan sengaja "mengonfrontasi" asas negara hukum dengan negara kekuasaan. Setelah perubahan undang-undang dasar, sebutan negara hukum dimasukkan ke dalam batang tubuh, dan tidak lagi dikonfrontasikan dengan negara kekuasaan. Ada kemungkinan, menurut Bagir Manan, para perumus merasa sudah cukup memindahkan Penjelasan yang bukan ketentuan UUD menjadi ketentuan UUD. Perdebatan-perdebatan dalam perubahan pertama undang-undang dasar di tahun 1999 jelas merekam dinamika tersebut.

Meskipun secara umum, ide negara hukum dalam batang tubuh disepakati, namun terdapat perbedaan prioritas pembahasan. Ada yang berpendapat karena pengaturan prinsip negara hukum sangat penting maka pembahasan harus dimasukkan sebagai priotas utama. Namun, ada pula yang berpendapat meskipun penting, namun pembahasan ditunda karena perumusan konsep hukum tidak mudah. Selain perdebatan-perdebatan negara hukum dalam sistematika UUD NRI 1945 serta waktu pembahasan, perdebatan lain menyangkut penggunaan kata dan istilah. Perbedaan menyangkut penggunaan 'negara berdasarkan hukum' atau cukup menggunakan 'negara hukum' dalam UUD 1945 merupakan diskusi yang banyak menyita waktu pada saat perumusan perubahan UUD NRI 1945. ${ }^{10}$

Pembahasan konsep negara hukum dilanjutkan pada tahun 2000 yang merupakan

10 Lihat Susi Dwi Hayanti, "Negara Hukum dalam Undang-Undang Dasar 1945" dalam Negara Hukum Yang Berkeadilan: Kumpulan Pemikiran dalam Rangka Purnabakti Prof. Dr. Bagir Manan, S.H., M.CL, ed. Susi Dwi Harijanti, Bandung: PSKN Unpad, 2011, hal. 90-95. tahun dilaksanakannya perubahan kedua UUD NRI 1945. Akan tetapi, tidak terdapat hal yang sangat substansial dalam perdebatan pada masa perubahan kedua ini. Justru pada pembahasan perubahan ketiga yang diadakan tahun 2001, mulai muncul diskusi-diskusi yang lebih substansial. Pembahasan mulai mengaitkan konsep negara hukum dengan demokrasi serta negara hukum dan hak asasi manusia. Terdapat sejumlah anggota perumus perubahan UUD 1945, yaitu Panitia Ad Hoc I Badan Pekerja MPR (PAH I BP MPR) yang ingin agar negara hukum yang menjunjung tinggi hak asasi manusia secara tegas dicantumkan dalam UUD NRI 1945. Sebaliknya, ada yang berpendapat bahwa dalam prinsip negara hukum secara implisit sudah terkandung perlindungan terhadap hak asasi manusia.

Berkenaan dengan penempatan negara hukum dalam sistematika UUD NRI 1945, pembahasan pada perubahan ketiga menunjukkan mulai terdapatnya titik temu antar para anggota PAH I BP MPR. Selain itu, perdebatan mengenai kaitan negara hukum dan demokrasi lebih mengemuka. Pembahasan selanjutnya dilakukan dalam sidangsidang Komisi A Sidang Tahunan MPR 2001, dengan pendapat yang masih terbelah, yakni antara mereka yang setuju pada rumusan alternatif pertama "Negara Indonesia adalah negara hukum" dan rumusan alternatif kedua "Indonesia adalah negara hukum yang demokratis", masing-masing dengan argumentasinya. Namun pada akhirnya, mayoritas anggota MPR lebih memilih rumusan pertama yaitu "negara hukum", kecuali Fraksi Reformasi, yang tetap pada pendiriannya memilih alternatif kedua yaitu "negara hu- 
kum yang demokratis". Pada rapat paripurna Sidang Tahunan MPR ke-7 tahun 2001, tanggal November 2001, disahkanlah hasil Komisi sebagai Perubahan Ketiga UUD NRI 1945, yang di dalamnya terdapat Pasal 1 ayat (3), yaitu "Negara Indonesia adalah negara hukum", dengan pemahaman bahwa demokrasi sudah terkandung dalam makna negara hukum itu. ${ }^{11}$

Terdapat beberapa pelajaran menarik yang dapat ditarik dari perdebatan konsep negara hukum dalam proses perubahan UUD NRI 1945, antara lain yaitu, ada keinginan untuk memasukkan prinsip negara hukum dalam batang tubuh, dengan cara memindahkannya dari penjelasan. Hal ini merupakan konsekuensi dari kesepakatan mengenai sistematika UUD NRI 1945 yang hanya akan terdiri dari Pembukaan dan pasal-pasal. Selain itu, prinsip negara hukum menjadikannya sebagai constitutional norm yang memiliki daya ikat lebih kuat dibandingkan sebelumnya. Berikutnya adalah, dimasukkannya prinsip negara hukum ke dalam Bab I UUD NRI 1945 menunjukkan bahwa Bab ini, antara lain, berfungsi sebagai umbrella bagi bab-bab selanjutnya. Pendapat ini menarik untuk disimak karena tanpa memberi judul bab secara eksplisit yang mencerminkan fungsi bab, ternyata Bab I dipahami sebagai payung yang menyediakan prinsipprinsip dasar bernegara. ${ }^{12}$

Perubahan UUD ini, telah mencantumkan prinsip-prinsip utama yang universal bagi sebuah negara hukum, yaitu antara lain penataan lembaga-lembaga negara yang menganut prinsip check and balances,

$11 \quad$ Ibid

12 Ibid. penegasan prinsip-prinsip independensi kekuasaan kehakiman serta pengakuan dan jaminan perlindungan hak-hak asasi manusia berseta pembatasannya. Hal lain yang perlu dicatat adalah dipertegasnya dalam konstitusi bahwa Indonesia adalah negara kesejahteraan dengan pengaturan terinci mengenai prinsip-prinsip negara kesejahteraan, antara lain pada Pasal 31, 32, 33 dan 34 UUD NRI 1945. Oleh karena, itu konstitusi Indonesia setelah perubahan tidak saja merupakan konstitusi politik tetapi juga merupakan konstitusi ekonomi dan konstitusi sosial budaya.

Mengamati perkembangan dan dinamika negara hukum Indonesia, tepatlah apa yang disimpulkan pada deklarasi New Delhi menganai rule of law pada tahun 1959, antara lain menegaskan:

"The rule of law means the principles, institutions, and procedures not always identical, but broadly similar, which the experience and tradition of lawyers in different countries of world, often having then self-varying political structures and economic backgrounds, have shown to be important to protect the individual from arbitrary government and to enable him to enjoy the dignity of man". ${ }^{13}$

Walaupun terdapat similiaritas dalam berbagai konsep negara hukum yang bersifat universal, namun seperti kenyataan dalam negara hukum Indonesia terdapat banyak ciri-ciri yang spesifik sebagai konsep dasar negara hukum Indonesia yang berbeda dengan konsep negara hukum lainnya. Hal itu telah diakui pula dengan kesepahaman secara internasional yang memberi pengakuan atas

13 Revision Workbook. (2002). Constitutional Law: The Machinery of Government, Third Edition, Charlton, London: Old Bailey Press, hlm. 33. 
keragaman pengalaman dan tradisi hukum di berbagai tempat dengan latar belakang struktur politik dan ekonomi yang bervariasi dan tidak harus sama atau dipaksa sama dengan negara lainnya yang juga merupakan negara hukum. Akan tetapi, pemaknaan negara hukum yang terlalu fleksible juga mengandung bahaya, karena negara hukum dapat juga dimaknai hanya rule by law, yaitu "law" (hukum) yang dibuat oleh penguasa yang otoriter yang harus dihormati tanpa syarat.

\section{Realitas Hukum di Era Reformasi Arah kebijakan hukum}

Salah satu tuntutan berbagai komponen bangsa pada ewal reformasi adalah penegakan supremasi hukum, yaitu membangun sistem hukum yang adil dan penegakkan hukum yang bersih dan berwibawa. Merespon tuntutan reformasi, maka reformasi hukum ini diawali dengan reformasi ketatanegaraan yang paling mendasar, yaitu reformasi konstitusi (constitutional reform). Sebab, konsitusi merupakan hukum dasar yang memiliki fungsi bagi penataan fungsi-fungsi lembaga negara, kerangka hukum hubungan antara warga masyarakat dengan negara.

Perubahan penting yang memberi dasar bagi peletakkan asas negara hukum demokratis, dalam kontek reformasi konstitusi, antara lain pada: (a) perubahan Pasal 1 ayat (2) UUD NRI 1945 yang memberi dasar bagi negara berdasarkan pada prinsip demokrasi konstitusional; (b) ditambahkannya pasalpasal mengenai hak asasi manusia, yaitu Pasal 28A sampai dengan Pasal 28J, yang memberi jaminan adanya perlindungan atas hak-hak asasi manusia; (c) dicantumkannya ketentuan mengenai Pemilihan umum (Pasal 22E); (d) pembentukan lembaga-lembaga baru yaitu Mahkamah Konstitusi dan Komisi Yudisial. Dengan reformasi konstitusi, supremasi hukum yang hendak ditegakkan adalah supermasi hukum dalam kerangka negara yang berdasarkan demokrasi dan konstitusi (Constitutional Democracy State).

Di era reformasi, produk hukum yang menentukan arah kebijakan hukum tersebut dituangkan dalam Ketetapan MPR No. IV/MPR/1999 tentang Garis-garis Besar Haluan Negara (GBHN) tahun 1999-2004. Namun seiring dengan perubahan kedudukan MPR dan ketatanegaraan, GBHN tidak lagi dikenal dalam sistem ketatanegaraan Indonesia. Oleh karenanya, pada periode selanjutnya, politik hukum dituangkan dalam Rencana Pembangunan Jangka Panjang dan Rencana Pembangunan Jangka Menengah sebagaimana yang ditetapkan Undang-Undang Nomor 17 tahun 2007 tentang Rencana Pembanguan Jangka Panjang Nasional tahun 2005-2025. Dalam undang-undang tersebut, terdapat beberapa komponen yang ingin diwujudkan dalam pembangunan di bidang hukum, yaitu: ${ }^{14}$

Pertama, pembangunan materi hukum yang diarahkan untuk melanjutkan pembaruan produk hukum untuk menggantikan peraturan perundang-undangan warisan kolonial yang mencerminkan nilai-nilai sosial dan kepentingan masyarakat Indonesia serta mendorong tumbuhnya kreativitas dan keterlibatan masyarakat untuk mendukung

14 Lihat Undang-Undang Nomor 17 tahun 2007 tentang Rencana Pembanguan Jangka Panjang Nasional tahun 2005-2025, Lembaran Negara RI tahun 2007 Nomor 33, Tambahan Lembaran Negara RI Nomor 4700. 
pelaksanaan penyelenggaraan pemerintahan dan pembangunan nasional yang mencakup perencanaan hukum, pembentukan hukum, penelitian dan pengembangan hukum. Pembentukan peraturan perundang-undangan yang baru, diarahkan untuk mengisi kekurangan atau kekosongan hukum sebagai pengarah dinamika lingkungan strategis yang sangat cepat berubah.

Perencanaan hukum sebagai bagian dari pembangunan materi hukum diselenggarakan dengan memerhatikan berbagai aspek yang memengaruhi, baik di dalam masyarakat sendiri maupun dalam pergaulan masyarakat internasional yang dilakukan secara terpadu dan meliputi semua bidang pembangunan sehingga produk hukum yang dihasilkan yang dapat memenuhi kebutuhan kehidupan masyarakat, bangsa, dan negara serta dapat mengantisipasi perkembangan zaman. Pembentukan hukum diselenggarakan melalui proses terpadu dan demokratis, sehingga menghasilkan produk hukum beserta peraturan pelaksanaan yang dapat diaplikasikan secara efektif dengan didukung oleh penelitian dan pengembangan hukum yang didasarkan pada aspirasi dan kebutuhan masyarakat. Penelitian dan pengembangan hukum diarahkan pada semua aspek kehidupan sehingga hukum nasional selalu dapat mengikuti perkembangan dan dinamika pembangunan yang sesuai dengan aspirasi masyarakat, baik kebutuhan saat ini maupun masa depan.

Kedua, pembangunan struktur hukum diarahkan untuk memantapkan dan mengefektifkan berbagai organisasi dan lembaga hukum, profesi hukum, dan badan peradilan sehingga aparatur hukum mampu melak- sanakan tugas dan kewajibannya secara profesional. Kualitas dan kemampuan profesionalisme aparatur hukum dikembangkan melalui sistem pendidikan dan pelatihan dengan kurikulum yang akomodatif terhadap setiap perkembangan pembangunan serta pengembangan sikap aparatur hukum yang menunjung tinggi kejujuran, kebenaran, keterbukaan dan keadilan, bebas dari korupsi, kolusi dan nepotisme, serta bertanggung jawab dalam bentuk perilaku yang teladan. Aparatur hukum dalam melaksanakan tugas dan kewajibannya secara profesional perlu didukung oleh sarana dan prasarana hukum yang memadai serta diperbaiki kesejahteraannya agar di dalam melaksanakan tugas dan kewajiban aparatur hukum dapat berjalan dengan baik dan terhindar dari pengaruh dan intervensi pihak-pihak dalam bentuk korupsi, kolusi, dan nepotisme.

Penerapan, penegakan hukum dan hak asasi manusia dilaksanakan secara tegas, lugas, profesional, dan tidak diskriminatif dengan tetap berdasarkan pada penghormatan terhadap hak asasi manusia, keadilan, dan kebenaran, terutama dalam penyelidikan, penyidikan, dan persidangan yang transparan dan terbuka dalam rangka mewujudkan tertib sosial dan disiplin sosial sehingga dapat mendukung pembangunan serta memantapkan stabilitas nasional. Penegakan hukum dan hak-hak asasi manusia dilakukan terhadap berbagai tindak pidana, terutama yang akibatnya dirasakan langsung oleh masyarakat luas, antara lain tindak pidana korupsi, kerusakan lingkungan, dan penyalahgunaan narkotik. Dalam rangka menjaga keutuhan wilayah Negara Kesatuan Republik Indonesia, penegakan hukum di laut secara terus- 
menerus harus ditingkatkan sesuai dengan kewenangan yang diatur dalam perundangundangan nasional dan hukum internasional. Pemantapan lembaga peradilan sebagai implikasi satu atap dengan lembaga Mahkamah Agung secara terus-menerus melakukan pengembangan lembaga peradilan; peningkatan kualitas dan profesionalisme hakim pada semua lingkungan peradilan; dukungan serta perbaikan sarana dan prasarana pada semua lingkungan peradilan sehingga dapat mengembalikan kepercayaan masyarakat terhadap citra lembaga peradilan sebagai benteng terakhir pencari keadilan.

Ketiga, di bidang budaya hukum, peningkatan dan perwujudan kesadaran hukum masyarakat yang tinggi. Memberi akses kepada masyarakat terhadap segala informasi yang dibutuhkan dan pelibatan dalam berbagai proses pengambilan keputusan pelaksanaan pembangunan nasional. Hal itu dimaksudkan agar setiap anggota masyarakat menyadari dan menghayati hak dan kewajibannya sebagai warga negara, sehingga terbentuk perilaku warga negara Indonesia yang mempunyai rasa memiliki dan taat hukum. Peningkatan perwujudan masyarakat yang mempunyai kesadaran hukum yang tinggi harus didukung oleh pelayanan dan bantuan hukum dengan biaya yang terjangkau, proses yang tidak berbelit, dan penetapan putusan yang mencerminkan rasa keadilan.

\section{Realitas pembangunan hukum}

Walaupun arah kebijakan pembangunan hukum telah dirumuskan dengan sangat jelas dan sangat baik, namun kenyataan dan kondisi hukum di Indonesia masih jauh dari harapan. Dari sisi pembentukan hukum, secara kwantitatif sejak tahun 1999 hingga
2012 terdapat 405 undang-undang yang dilahirkan. ${ }^{15}$ Sampai saat ini, terdapat 178 undang-undang, yang diuji ke Mahkamah Konstitusi. ${ }^{16}$ Bahkan dari jumlah tersebut, 5 undang-undang telah dibatalkan secara keseluruhan oleh Mahkamah Konstitusi. ${ }^{17}$

Secara umum, hal ini mengindikasikan bahwa kualitas pembentukan undang-undang masih banyak mengandung persoalan. Seperti ditemukan dalam berbagai perkara yang diadili di Mahkamah Konstitusi, kelemahan pada banyak undang-undang adalah pada sinkronisasi dan konsistensi baik secara vertikal dengan norma UUD, maupun horisontal antara undang-undang yang satu dengan yang lainnya bahkan sinkronisasi dalam antar norma satu undangundang. Artinya disamping banyak undangundang yang tidak memperhatikan normanorma konstitusi, juga banyak ditemukan antara undang-undang yang satu dengan undang-undang yang lain atau antara satu norma dengan norma yang lain dalam satu undang-undang saling bertentangan dan tidak konsisten.

15 Data diperoleh dari http://www.dpr.go.id/id/uudan-ruu/undang-undang, diakses tanggal 3 September 2012.

16 Data diperoleh dari Kepaniteraan dan Sekretariat Jenderal Mahkamah Konstitusi Republik Indonesia, tanggal 6 September 2012

17 Lima undang-undang yang dibatalkan (dari tahun 2003-2012) tersebut adalah (1) UU No. 16 tahun 2003 Tentang Penetapan Perpu No. 2 Tahun 2002 tentang Pembentukan UU no. 15 tahun 2002 Jo. Perpu No. 1 tahun 2002 tentang Pemberantasan Tindak Pidana Terorisme, (2) UU No. 20 tahun 2002 Tentang Ketenagalistrikan; (3) UU No. 27 tahun 2004 Tentang Komisi Kebenaran dan Rekonsiliasi; (4) UU No. 9 tahun 2009 Tentang Badan Hukum Pendidikan; (5) UU No. 45 tahun 1999 Tentang Pembentukan Irian Jaya Tengah, Provinsi Irian Jaya Barat, Kabupaten Paniai, Kabupaten Timika, kabupaten Puncak Jaya dan Kota Sorong. 
Dalam banyak kasus yang dibawa ke Mahkamah Konstitusi, ditemukan banyak undang-undang yang mengabaikan prinsipprinsip yang dianut oleh UUD 1945. Beberapa contoh yang dapat dikemukakan antara lain:

Pertama, dalam bidang hak-hak politik, Mahkamah Konstitusi secara tegas melalui putusannya merehabilitasi hak-hak politik eks PKI dan tahanan politik yang mencalonkan diri sebagai anggota legislatif. Mahkamah Konstitusi memberi perlindungan dan jaminan tidak adanya perlakuan diskriminatif berdasarkan agama, suku, ras, etnik, kelompok, golongan status sosial, status ekonomi, jenis kelamin, bahasa dan keyakinan politik. ${ }^{18}$

Kedua, dalam bidang demokrasi, Mahkamah Konstitusi secara nyata menjamin terlaksananya prinsip kedaulatan rakyat di daerah dengan menekankan bahwa penyelenggaraan Pilkada langsung harus berdasarkan asas-asas Pemilu, yakni langsung, umum, bebas, rahasia, jujur, dan adil serta diselenggarakan oleh penyelenggara yang independen (mandiri). ${ }^{19}$

Ketiga, dalam bidang sosial, Mahkamah Konstitusi melalui putusannya telah membatalkan Undang-Undang Badan Hukum Pendidikan dan pasal-pasal dalam Un-

18 Lihat Putusan Mahkamah Konstitusi Nomor 11-017/PUU-I/2003 Perihal Pengujian UndangUndang Nomor 12 tahun 2003 tentang Pemilihan Umum Anggota Dewan Perwakilan Rakyat, Dewan Perwakilan Daerah, dan Dewan Perwakilan Rakyat Daerah terhadap Undang-Undang Dasar Negara Republik Indonesia Tahun 1945.

19 Lihat Putusan Mahkamah Konstitusi 072-073/ PUU-II/2004 Perihal Pengujian Undang-Undang Nomor 32 tahun 2004 tentang Pemerintah Daerah terhadap Undang-Undang Dasar Negara Republik Indonesia Tahun 1945.
dang-Undang Sistem Pendidikan Nasional yang dianggap bertentangan dengan kewajiban negara untuk mencerdaskan kehidupan bangsa, karena dalam undang-undang tersebut memberi peluang untuk terjadinya liberalisasi pendidikan yang hanya menguntungkan kelompok masyarakat yang kaya dan merugikan masyarakat yang miskin. ${ }^{20}$

Keempat, dalam bidang agama, Mahkamah Konstitusi dengan putusannya terhadap Undang-Undang Penodaan Agama telah memberikan warna atas prinsip negara hukum Indonesia, yang pada prinsipnya tidak memisahkan antara agama dan negara. Dalam hal ini, negara diberi peran untuk masuk dalam mengurus masalah-masalah yang berkaitan dengan agama khususnya apabila bersentuhan dengan ketertiban umum. ${ }^{21}$

Kelima, dalam bidang ekonomi, Mahkamah Konstitusi mempertahankan ideologi ekonomi yang dianut UUD 1945, yaitu, ideologi yang menganut welfare state. Dalam hal ini, negara harus mengarahkan dan mengendalikan kebijakan ekonomi dan pasar khususnya yang terkait dengan sumber daya alam dan sumber produksi yang menyangkut hajat hidup orang banyak. Oleh karena itulah, Mahkamah Konstitusi membatalkan Undang-Undang Ketenagalistrikan ${ }^{22}$ dan

20 Lihat Putusan Mahkamah Konstitusi Nomor 1114-21-126-136/PUU-VII/2009 Perihal Pengujian Undang-Undang Nomor 20 Tahun 2003 tentang Sistem Pendidikan Nasional dan Undang-Undang Nomor 9 Tahun 2009 tentang Badan Hukum Pendidikan terhadap Undang-Undang Dasar Negara Republik Indonesia Tahun 1945.

21 Lihat Putusan Mahkamah Konstiutsi Nomor 140/PUU-VII/2009 Perihal Pengujian UndangUndang Nomor 1/PNPS/Tahun 1965 tentang Pencegahan Penyalahgunaan dan/atau Penodaan Agama terhadap Undang-Undang Dasar Negara Republik Indonesia Tahun 1945.

22 Lihat Putusan Mahkamah Konstitusi Nomor 001- 
Undang-Undang Sumber Daya Air $^{23}$ serta Undang-Undang Pengelolaan Wilayah Pesisir dan pulau-pulau kecil, karena undangundang tersebut dianggap mengancam hajat hidup orang banyak dan terlalu pro pada liberalisasi. $^{24}$

Walaupun dari sisi pembentukan undang-undang, masih banyak kekurangan baik kwantitas maupun kwalitasnya, tetapi secara umum tidak sebesar persoalan yang dihadapi dalam penegakkan hukum oleh institusi peradilan. Oleh karena bidang penegakkan dan pelayanan hukum menyentuh langsung denyut kehidupan rakyat, maka persoalan penegakan dan pelayanan hukum, khususnya oleh berbagai institusi peradilan selalu menjadi perhatian besar dari masyarakat dan pegiat hukum.

Reformasi hukum dalam bidang peradilan yang dianggap positif hanyalah pada keberadaan tiga lembaga peradilan baru yang dibentuk pada awal reformasi yaitu, Mahkamah Konstitusi, Komisi Pemberantasan Korupsi (KPK) serta Komisi Yudisial (KY). Di samping, karena ketiga lembaga ini adalah lembaga baru, sehingga sedikit banyak tidak terkontaminasi oleh pengalaman praktik hukum sebelum reformasi, juga ter-

021-022/PUU-I/2003 Perihal pengujian Undangundang Nomor 20 Tahun 2002 tentang Ketenagalistrikan terhadap Undang-Undang Dasar Negara Republik Indonesia Tahun 1945.

23 Lihat Putusan Mahkamah Konstitusi Nomor 5859-60-63/PUU-II/2004 Perihal pengujian Undang-undang Republik Indonesia Nomor 7 Tahun 2004 tentang Sumber Daya Air terhadap UndangUndang Dasar Negara Republik Indonesia Tahun 1945.

24 Lihat Putusan Mahkamah Konstitusi Nomor 3/ PUU-VIII/2010 Perihal Pengujian undang-undang nomor 27 tahun 2007 tentang Pengelolaan wilayah pesisir dan pulau-pulau kecil terhadap UndangUndang Dasar Negara Republik Indonesia Tahun 1945. dapat tekat dan semangat yang kuat dari para penegak hukum di ketiga lembaga ini untuk tetap menjaga kinerja dan kepercayaan rakyat. Dengan adanya Mahkamah Konstitusi, kajian dan perkembangan hukum tata negara menjadi sangat dinamis dan berkembang sangat cepat. Di berbagai forum internasional, keberadaan Mahkamah Konstitusi Indonesia dianggap sebagai salah satu Mahkamah Konstitusi yang berhasil menjalankan fungsinya dengan baik dalam menegakkan prinsip negara hukum dan prinsip demokrasi sesuai bidang kewenangannya. Managemen peradilan yang berbasis teknologi informasi sehingga mempercepat pemberian pelayan hukum dan akses terhadap pengadilan yang dilakukan oleh Mahkamah Konstitusi Indonesia sering dijadikan model oleh lembaga peradilan di negara-negara lain.

Demikian juga dengan KPK, dianggap sebagai lembaga peradilan berwibawa dan paling ditakuti oleh siapa pun yang mencoba melakukan korupsi. Walaupun lembaga ini, memiliki kelemahan karena kurangnya sumberdaya yang dimiliki dihadapkan pada tuntutan penyelesaian perkara korupsi yang jumlahnya sangat banyak, tetapi KPK dianggap telah secara maksimal menjaga profesionalitasnya dalam menegakkan hukum. Begitu pula dengan lembaga-lembaga lainnya yang dianggap sebagai produk reformasi seperti Komisi Hak Asasi Manusia (walaupun komisi ini terbentuk pada masa akhir Orde Baru), Komisi Ombusman Nasional, Komisi Pengawas Persaingan Usaha, Komisi Perlindungan Saksi dan lembaga lainnya yang masih menunjukkan kewibawaan yang lebih baik dibanding institusi peradilan yang telah lama, seperti pengadilan, kejaksaan 
dan kepolisian.

Institusi pengadilan, kejaksaan dan kepolisian adalah institusi peradilan yang paling banyak bersentuhan langsung dengan perasaan hukum dan keadilan dalam masyarakat, sehingga ketiga institusi ini selalu menjadi sorotan. Banyak persoalan yang menyelimuti ketiga lembaga peradilan ini yang harus menjadi perhatian negara untuk diperbaiki. Mulai dari masalah profesionalisme dan integritas para penegak hukum, managemen dan administrasi peradilan sampai pada masalah sarana dan prasarana peradilan. Demikian juga masalah akuntabilitas dan transparansi penanganan dan penyelesaian perkara (dalam batas-batas yang harus dilakukan) serta pertanggunganjawaban institusional masih jauh dari harapan.

Di bidang budaya hukum, era reformasi yang ditandai dengan meningkatnya arus informasi dan komunikasi telah memengaruhi pola dan tingkat kesadaran hukum masyarakat. Fenomena yang berkembang saat ini, masyarakat cenderung menempuh jalur hukum ketika hak-haknya tidak terpenuhi, atau dalam bidang politik terlihat dengan ikutnya masyarakat dalam proses pembentukan rancangan undang-undang. Akan tetapi, jika diukur dari tingkat kepatuhan hukum, kesadaran hukum masyarakat tersebut masih sangat jauh dari harapan. Contoh paling nyata antara lain, ketaatan terhadap aturan lalu lintas, penghormatan atas lembaga peradilan dan putusan lembaga peradilan.

Pada sisi lain, reformasi dan demokratisasi sering dimaknai secara berlebihan terutama dalam menempatkan hak asasi manusia, sehingga dengan tameng kebebasan dan hak asasi manusia sering terjadi pemaksaan kehendak dan tindakan "main hakim sendiri" seperti dalam bentuk pengadilan rakyat (eigenricting), ataupun adanya tindakan perusakan dan penghacuran berbagai sarana dan prasarana publik ketika aspirasi mereka tidak tersalurkan. Sebagai contoh, pelaksanaan pemilukada misalnya, justru menenggelamkan jati diri masyarakat pada sikap yang menjurus anarkis-destruktif, sektarianisme, lokal-etnisentris, dan bahkan syahwat kekuasaan yang berlebihan sehingga menghalakan segala cara. Kenyataan-kenyataan demikian mencerminkan rendahnya budaya dan kesadaran hukum masyarakat. Tidak nampak adanya upaya-upaya sistematis dan terencana dalam membangun dan meningkatkan kesadaran hukum masyarakat itu.

\section{Prospek Negara Hukum Indonesia}

Sebagaimana yang telah diuraikan diatas bahwa tiga pilar sistem hukum yang harus terus diperkuat agar reformasi hukum dapat terus berlanjut adalah substansi hukum, struktur hukum, dan kultur hukum. ${ }^{25}$ Berbicara mengenai substansi hukum, sangat terkait dengan materi peraturan perundangundangan. Disadari atau tidak, sulitnya penegakkan hukum di Indonesia sudah diawali dari pembuatan peraturan perundangan. ${ }^{26}$ Oleh karenanya, untuk meningkatkan kualitas produk legislasi paling tidak harus memerhatikan beberapa aspek, yaitu: Pertama, harmonisasi dan sinkronisasi substansi peraturan perundang-undangan yang

25 Lawrence M. Friedman, American Law Introduction, Hukum Amerika sebuah pengantar, penerjemah: Wishnu Basuki, Jakarta: Tatanusa, 2001, hal. 6-8.

26 Hikmahanto Juwana. "Ikatan Hakim Indonesia", Varia Peradilan, Majalah Hukum, 21(244) Maret 2006: 56. 
berlaku, sehingga terhindar dari adanya tumpang tindih, kekurangjelasan, multi-tafsir, serta sinkronisasi dengan nilai-nilai falsafah bangsa dan norma konstitusi. Kedua, seluruh peraturan perundang-undangan tidak boleh mengandung sedikit pun kemungkinan untuk digunakan sebagai celah melakukan korupsi, kolusi, nepotisme dan benturan kepentingan fungsi pejabat publik. Ketiga, peraturan perundangan harus bisa mengubah masyarakat menjadi modern, berpendidikan, dan memiliki daya saing dengan bangsa-bangsa lain di dunia, serta menjamain tumbuhnya masyarakat terbuka yang menghargai pluralisme, tanpa melupakan jati diri bangsa ini. Keempat, seluruh peraturan perundang-undangan yang berlaku mampu menggerakkan ekonomi dengan pasrtisipasi rakyat yang luas, mencapai angka pertumbuhan ideal, membuka kesempatan kerja dan usaha yang berkeadilan dan menyejahterakan semua bagian masyarakat Indonesia.

Aspek lain yang patut diperhatikan adalah perlu mengubah paradigma pembangunan hukum melalui pendekatan peraturan peraturan perundang-undangan atau pendekatan legislatif menjadi pendekatan pada aspek penegakan hukum oleh institusi peradilan. Kondisi ini terkait dengan pilar berikutnya yaitu struktur hukum, yang dalam hal ini berhubungan dengan institusi dan kelembagaan hukum, karena keberadaan substansi hukum tidak akan bermakna jika tidak didukung oleh struktur sebagai perangkat yang menjalankan dan menegakkan hukum. Tantangan utama reformasi bidang hukum adalah bagaimana memposisikan institusi peradilan sebagai lembaga yang berwibawa. Faktor terakhir inilah yang justru menampakkan jatuhnya wibawa hukum di Indonesia dan merosotnya kepercayaan publik terhadap hukum.

Kelanjutan reformasi yudisial tidak hanya menyangkut kelembagaan, tetapi juga pelaku utama institusi oeradilan yaitu hakim-hakim, pejabat dan pegawai peradilan, jaksa, polisi serta pengacara yang akan melaksanakan fungsi peradilan. Posisi para aparat penegak hukum menjadi sangat vital. Para penegak hukum, seharusnya tidak terpaku dan berlindung pada asas legalitas dan kepastian hukum secara kaku. Hal terpenting adalah harus benar-benar menghayati "suasana kebatinan" negara hukum Indonesia, yang bersifat mengayomi, menghargai keragaman, serta menjunjung tinggi keadilan.

Orientasi reformasi hukum seperti dirakan di atas, tentu tentu tidak semata-mata bergantung pada kelembagaan atau institusi peradilan serta aparatnya, tetapi juga bergantung pada kesadaran hukum masyarakat yang memiliki keyakinan dan kesadaran bahwa "proses hukum itu merupakan suatu cara penyelesaian terbaik, dan bahwa prinsip-prinsipnya adalah harus dihormati”. Jadi, jika ada keyakinan yang kuat bahwa hukum adalah di atas segala-galanya, masyarakat akan menggunakan hukum atau akan selalu kembali pada penyelesaian hukum dan tidak mengambil tindakan hukum sendiri. Jadi, hukum mengatasi kepentingan-kepentingan individu dan golongan. Kesadaran seperti itu belum menjadi budaya dalam kehidupan sehari-hari masyarakat kita.

Negara hukum modern, tentu tidak dapat dibatasi dengan asas legalitas yang kaku dalam arti, para penyelenggara hanya 
dapat bertindak berasaskan aturan-aturan hukum yang formal dan kaku, padahal sering mengorbankan keadilan. Oleh karenanya, untuk menjalankan tugasnya dengan sempurna, para penyelenggara negara, khususnya para penegak hukum seharusnya selalu berpikir dan bertindak berdasarkan kepentingan umum, dengan memperhatikan asas-asas hukum yang berlaku serta rasa keadilan. ${ }^{27}$

Reformasi bidang penegakkan hukum adalah sebuah keniscayaan (necessary condition) yang tidak bisa dielakkan. Peraturan hukum yang baik, yang memenuhi prinsipprinsip logika, menjadi tidak bermakna jika aparat pelaksananya tidak mau menggunakan logika dan akal sehat (common sense). Apapun risikonya, pilihan untuk mereformasi total institusi ini harus terus didorong. Di samping itu, reformasi hukum juga menjadi porsi dan tanggung jawab perguruan tinggi. Kampus-kampus perlu melakukan kajian sekaligus mereformasi kurikulum yang diajarkan dalam kuliah hukum, karena produk perguruan tinggi ini yang akan menjadi pilar penegakan hukum. Sekali lagi, orientasi pada penelitian, pengembangan dan kebijakan hukum harus lebih difokuskan pada aspek penegakkan hukum ini.

\section{PENUTUP}

Membangun negara hukum bagi Indonesia adalah mandat konstitusi. Meskipun demikian, seperti kata Satjipto Rahardjo, membangun negara hukum itu bukanlah sekedar menancapkan papan nama. Ia adalah proyek

27 Yusril Ihza Mahendra. (1996). Dinamika tatanegara Indonesia Kompilasi Aktual Masalah Konstitusi Dewan Perwakilan dan Sistem Kepartaian: Jakarta: Gema Insani Press, hal. 42-44 raksasa yang menguras tenaga. Lebih dari dasawarsa terakhir, Indonesia telah banyak melakukan perubahan untuk mewujudkan cita negara hukum. Perubahan konstitusi, pembentukan sejumlah peraturan perundang-undangan, pembentukan lembagalembaga negara baru, pembenahan institusi dan aparat penegak hukum telah dilakukan. Namun pembangunan hukum terasa masih tetap jauh dari harapan.

Keberhasilan membangun negara hukum tidak dapat diukur dari kemampuan memproduksi legislasi dan menciptakan atau merevitalisasi institusi hukum. Lebih dari itu, keberhasilan bernegara hukum harus pula diukur dari implementasi dan penegakan hukum yang mampu menciptakan keadilan bagi seluruh rakyat. Sejauhmana kepuasan rakyat atas pelayanan hukum dan akses terhadap keadilan. Oleh karena itu, fokus utama berbagai kajian hukum dan kebijakan hukum, harus diorientasikan pada institusi peradilan dan penegakkan hukum. Selama ini kita terlalu banyak berorientasi pada legislasi dan pembentukan hukum atau penelitian hukum yang berkaitan dengan pembentukan norma hukum, tetapi banyak mengabaikan penelitian dan perhatian atas institusi peradilan dan penegakan hukum. Pada aspek itulah denyut nadi rasa keadilan masyarakat dirasakan secara langsung.

\section{BIBLIOGRAFI}

Bambang Arumanadi dan Sunarto. (1993). Konsepsi Negara Hukum Menurut UUD 1945. Semarang: IKIP Semarang Press.

Dicey, A.V. (2008). Introduction to the study of the Law and the Constitution, Ninth Edition, London: MacMilland and Co. 
1952. Terjemahan Bahasa Indonesia, Pengantar Studi Hukum Konstitusi, Oleh Nurhadi, MA. Bandung: Nusa Media.

Friedman, Lawrence M. (2001). American Law Introduction, Hukum Amerika sebuah pengantar, penerjemah: Wishnu Basuk. Jakarta: Tatanusa.

Hikmahanto Juwana. (2006). "Ikatan Hakim Indonesia”, Varia Peradilan, Majalah Hukum, 21(244): 56.

Oemar Seno Aji. (1980). Peradilan Bebas Negara Hukum, Jakarta: Erlangga.

Revision Workbook. (2002). Constitutional Law: The Machinery of Government, Third Edition, Charlton, London: Old Bailey Press.

Satjipto Rahardjo. (2009). Negara Hukum yang Membahagiakan Rakyatnya, Cetakan kedua. Yogyakarta: Genta Publishing.

Sunaryati Hartono. (1969). Apakah the Rule of Law. Bandung: Alumni.

Sekretariat Jenderal dan Kepaniteraan Mahkamah Konstitusi. (2009). Proceeding Kongres Pancasila: Pancasila dalam Berbagai Perspektif. Jakarta: Sekretariat Jenderal dan Kepaniteraan Mahkamah Konstitusi.

Susi Dwi Hayanti (ed). (2011). Negara Hukum Yang Berkeadilan: Kumpulan Pemikiran dalam Rangka Purnabakti Prof. Dr. Bagir Manan, S.H., M.CL. Bandung: PSKN Unpad.

Tamanaha, Brian Z. (2004). On The Rule Of Law. Cambridge: Cambridge University Press.

. (2006). Law as a means to an end (Law in context). Cambridge: Cambridge University Press.

Yusril Ihza Mahendra. (1996). Dinamika tatanegara Indonesia Kompilasi Ak- tual Masalah Konstitusi Dewan Perwakilan dan Sistem Kepartaian: Jakarta: Gema Insani Press.

Putusan Mahkamah Konstitusi:

Putusan Mahkamah Konstitusi Nomor 11017/PUU-I/2003 Perihal Pengujian Undang-Undang Nomor 12 tahun 2003 tentang Pemilihan Umum Anggota Dewan Perwakilan Rakyat, Dewan Perwakilan Daerah, dan Dewan Perwakilan Rakyat Daerah terhadap Undang-Undang Dasar Negara Republik Indonesia Tahun 1945.

Putusan Mahkamah Konstitusi Nomor 1114-21-126-136/PUU-VII/2009 Perihal Pengujian Undang-Undang Nomor 20 Tahun 2003 tentang Sistem Pendidikan Nasional dan Undang-Undang Nomor 9 Tahun 2009 tentang Badan Hukum Pendidikan terhadap Undang-Undang Dasar Negara Republik Indonesia Tahun 1945.

Putusan Mahkamah Konstiutsi Nomor 140/ PUU-VII/2009 Perihal Pengujian Undang-Undang Nomor 1/PNPS/Tahun 1965 tentang Pencegahan Penyalahgunaan dan/atau Penodaan Agama terhadap Undang-Undang Dasar Negara Republik Indonesia Tahun 1945.

Putusan Mahkamah Konstitusi Nomor 001021-022/PUU-I/2003 Perihal pengujian Undang-undang Nomor 20 Tahun 2002 tentang Ketenagalistrikan terhadap Undang-Undang Dasar Negara Republik Indonesia Tahun 1945.

Putusan Mahkamah Konstitusi Nomor 5859-60-63/PUU-II/2004 Perihal pengujian Undang-undang Republik Indonesia Nomor 7 Tahun 2004 tentang Sumber Daya Air terhadap UndangUndang Dasar Negara Republik Indonesia Tahun 1945. 